\title{
UPACARA ADAT KELAHIRAN SEBAGAI NILAI SOSIAL BUDAYA PADA MASYARAKAT SUKU SASAK DESA PENGADANGAN
}

\author{
Suhupawati, M.Pd', Dian Eka Mayasari S.W, M.Pd² \\ ${ }^{1}$ Pendidikan Sejarah, Universitas Hazawadi Lombok Timur, cuupa.althaf@yahoo.com \\ ${ }^{2}$ Program Studi Pendidikan Sejarah, Universitas Muhammadiyah Mataram, dianekamaya30s@gmail.com
}

\section{INFO ARTIKEL}

RiwayatArtikel:

Diterima: 02-11-2017

Disetujui: 13-12-2017

\section{Kata Kunci:}

1. Kelahiran

2. Sosial Budaya

\section{A. LATAR BELAKANG}

Masyarakat Suku Sasak Lombok merupakan masyarakat yang masih memegang teguh tradisi dan adat istiadatnya, karena merupakan warisan leluhur mereka. Kehidupan sehari-hari masyarakat Suku Sasak Lombok sarat dengan ritual. Meskipun ritus peralihan berasal dari agama islam tetapi tujuan dari penyelenggaraan upacara ritual tersebut untuk melestarikan budaya leluhur. Pada masyarakat Bayan mengenal beberapa peristiwa yang menandai siklus kehidupan manusia. Peristiwa-peristiwa yang utama adalah kelahiran, perkawinan, mempunyai anak, dan meninggal dunia. Sedangkan peristiwa yang lainnya menyangkut tahapan-tahapan kehidupan dari masa kanak-kanak hingga meninggal dunia. Ritual yang dilakukan oleh masyarakat Bayan tidak jauh berbeda dengan ritual yang dilakukan oleh masyarakat Suku Sasak yang berada di Desa Pengadangan. Meskipun masyarakat Desa Pengadangan juga sebagian besar beragama islam tetapi mereka tetap melakukan ritual-ritual dalam pelaksanaan upacara adat. Masyarakat Desa Pengadangan mempercayai bahwa roh leluhur dan mahluk halus menempati benda-benda mati atau tempat yang dikeramatkan. Masyarakat Pengadangan menganggap bahwa leluhur mereka mempunyai hubungan yang lebih dekat dengan Tuhan. Mereka memandang para leluhur sebagai perantara yang bisa berhubungan dengan Tuhan mewaikili mereka. Masyarakat percaya bahwa leluhur bisa membawa berkah Tuhan, maupun memberikan 
perlindungan terhadap anak keturunan yang masih hidup terutama dalam kesejahteraan masyarakat.

Adanya kenyakinan masyarakat Desa Pengadangan terhadap para leluhurnya, sehingga sesuatu yang dianggap sebagai pantangan (pamalik) harus diupacarakan. Apabila melanggar aturan adat yang sudah ditentukan maka akan mengakibatkan sanksi dalam kaitannya dengan supranatural. Sanksi ini tewujud dalam berbagai hukuman fisik dan batin yang diakibatkan kepada anak keturunan yang masih hidup.Untuk itu, hubungan baik dengan para leluhur dijaga secara terus-menerus sehingga arwah leluhur tidak marah dan memutus rantai hubungan antara orang yang masih hidup dengan Sang Pencipta. Kepercayaan masyarakat Desa Pengadangan terhadap leluhurnya masih melekat dan diyakini secara konsisten, sehingga dapat berpengaruh terhadap kehidupan sehari-hari kepada para penganutnya. Pengaruh yang paling nampak dilihat dari ritual-ritual atau tradisi pada masa peralihan dimana masyarakat mengalami berbagai lintasan kehidupan.Lintasan kehidupan dilakukan oleh masyarakat Desa Pengadangan sebagai suatu upacara adat untuk memohon perlindungan kepada Tuhan.

Ritual yang masih berhubungan dengan sistem kehidupan masyarakat yaitu upacara adat kelahiran sebagai keseluruhan siklus kehidupan manusia, meliputi upacara masa Beretes/Retesembet (masa hami 7 bulanan), MolangMaliq/pemberian nama pada bayi, Ngurisang/pemotongan rambut, dan Nyunatang/khitanan (budiwanti, 2000: 184). Upacara adat kelahiran ini merupakan upacara yang dinantikan oleh setiap orang karena berhubungan dengan kelahiran sang anak. Upacara adat ini berhubungan dengan keteladanan, kewibawaan dan identitas diri dalam norma dan nilai-nilai masyarakat sebagai lambang dalam suatu upacara adat. Upacara adat kelahiran ini memiliki arti yang melambangkan suatu budaya tradisional sebagai tanda syukur, keselamatan, kemandirian, kebahagiaan, tanggung jawab, solidaritas, kejujuran, kasih sayang, dan doa. kesemua ini merupakan nilai-nilai sosial budaya yang ada pada pelaksanaan upacara adat kelahiran. Seperti dalam upacara Besembet atau Retesembet bermakna nilai keselamatan dan nilai syukur, upacara MolangMaliq dan Ngurisang bermakan tanggung jawab dan ketulusan, upacara Nyunatang bermakna ketulusan dan kebahagiaan. Masyarakat Desa Pengadangan beranggapan bahwa apabila upacara adat kelahiran ini dilaksanakan, maka akan tercipta rasa aman bagi kehidupan masyarakat yang bersumber dari Tuhan Yang Maha Esa dan terhadap budaya leluhur mereka.

Matitaputty (2010: 6) menyatakan bahwa upacara daur hidup pada masa sekarang ini cenderung mengalami penyederhanaan-penyederhanaan baik sarana maupun prosesinya. Kebanyakan masyarakat pada masa kini sudah tidak lagi mengetahui prosesi lengkap dan tata cara serta sarana yang utuh dalam penyelenggaraan suatu upacara atau ritual dalam suatu upacara adat. Hampir sebagian besar telah dipengaruhi oleh kegiatan-kegiatan budaya barat, baik seperti cara berpakaian, bergaul, dan lain sebagainya pada akhirnya kebudayaan asli daerah dengan nilai luhur yang terkandung di dalamnya akan hilang dari masyarakat secara keseluruhan. Pola kehidupan pada masyarakat Desa Pengadangan secara tidak sadar telah mulai meninggalkan bentuk-bentuk kehidupan baru dengan segala kemudahannya.Tetapi dalam pelaksanaan ritual upacara adat kelahiran masih tetap dilaksnakan meskipun dipengaruhi oleh budaya asing. Masyarakat Desa Pengadangan tetap melaksanakan adat seperti yang dilakukan oleh leluhur mereka meskipun dalam kemelut peradaban dunia saat ini. Oleh karena itu dalam penelitian ini perlu dikaji proses pelaksanaan ritual adat kelahiran ini sehingga fungsi dan nilai-nilai dari adat kelahiran tersebut tetap terjaga dan berlaku dalam masyarakat seutuhnya.

\section{B. METODE PENELITIAN}

Penelitian ini menggunakan metode kualitatif dengan pendekatan etnografi. Sebagaimana yang dinyatakan Koentjaraningrat (2002: 329) melihat penelitian kualitatif ini sebagai penelitian yang bersifat etnografi yaitu suatu deskripsi mengenai suatu kebudayaan suatu bangsa dengan pendekatan antropologi. Lokasi penelitian yang dipilih adalah Desa Pengadangan Kecamatan Pringgasela Kabupaten Lombok Timur. Data yang diperoleh berupa data primer yakni data yang langsung diperoleh dari sumber data dan data sekunder yakni data yang tidak langsung diperoleh dari pengumpulan data berupa arsip-arsip yang diperoleh dari 
lokasi penelitian. Teknik pengumpulan data dalam penelitian ini menggunakan observasi, wawancara dan dokumentasi.

Analisis data yang digunakan adalah reduksi data, penyajian data, dan penarikan kesimpulan atau verifikasi. Validasi data dilakukan dengan menggunakan teknik triangulasi dengan pemeriksaan melalui data atau sumber lainnya dengan jalan membandingkan dan mengecek baik derajad suatu informasi yang diperoleh melalui waktu dan alat yang berbeda sehingga dapat diuji validasinya.

\section{HASIL DAN PEMBAHASAN}

Masyarakat Suku Sasak mengenal dan memiliki bentuk-bentuk budaya sendiri yang merupakan bentuk perilaku masyarakatnya. Kebudayaan dimaksud dapat berupa tata kelakuan masyarakat, bahasa, sistem kepercayaan, upacara-upacara adat dan sebagainya.Sehingga, dalam kehidupan masyarakat Suku Sasak dikenal adanya beberapa bentuk kebudayaan yang meliputi tahapan-tahapan penting bagi tiap-tiap individu dalam masa pertumbuhan dan perkembangannya sejak masa sebelum lahir,masa kelahiran,masa anak-anak,masa remaja,masa dewasa,masa perkawinan hingga dengan saat kembali kehadirat Tuhan Yang Maha Esa.Masyarakat juga mengenal berbagai peristiwa yang menandai siklus kehidupan manusia.Peristiwa-peristiwa yang utama adalah peristiwa yang menyangkut tahapan-tahapan kehidupan yaitu masa kanak-kanak, masa akil balik, dan masa dewasa.Sebagaimana dinyatakan Taylor dalam Budiwanti (2000: 182) bahwa ritus peralihan merupakan respon cultural langsung terhadap faktor-faktor biologis, perubahan psikologis dan tahapan kehidupan manusia.Tradisi-tradisi yang ada pada masyarakat Suku Sasak ini sebagai upacara keagamaan untuk mencari hubungan antara manusia dengan Tuhan dan mahluk yang mendiami alam ghaib yang dilambangkan dalam bentuk kepercayaan orang Sasak pada waktu upacara berdoa dan melakukan sesaji. Setiap melakukan upacara adat masyarakat Suku Sasak tidak terlepas dengan pemanjatan doa kepada Tuhan dan penggunaan sesaji disetiap prosesi adat.
Upacara adat kelahiran sebagai upacara adat yang diwariskan oleh nenek moyang leluhur dari masyarakat Suku Sasak.upacara adat kelahiran ini sebagai upacara yang sangat menegangkan dan sangat rentan dengan bahanya menurut orang Sasak, sehingga masyarakat Suku sasak menyelenggarakan upacara selametan dan pembacaan doa agar terhindar dari bahanya tersebut. Masyarakat Suku Sasak memiliki kepercayaan bahwa setiap kehidupan melewati rangkaian siklus kehidupan dari ia dilahirkan sampai meninggal dunia. Saat manusia dilahirkan harus melewati beberapa ritual dalam kehidupannya yaitu upacara beretes (menghormati ariari), molang maliq (pemberian nama pada bayi), ngurisang (pencukuran rambut), dan nyunatang (khitanan). Dari beberapa ritual yang melingkupi hidup manusia tersebut, upacara daur hidup ini berhubungan dengan ritual yang dilakukan oleh masyarakat Suku Sasak yang menyimpan begitu banyak makna yang belum banyak diketahui oleh sebagian besar masyarakat Indonesia khususnya masyarakat Suku Sasak Desa Pengadangan terdapat berbagai macam tradisi dalam kehidupan masyarakat Suku Sasak yang harus dipertahankan dari arus globalisasi seperti sekarang ini dan terdapat keunikan-keunikan tersendiri dari upacara adat tersebut dibandingkan dengan ritual-ritual lainnya.

Ritual upacara daur hidup merupakan salah satu unsur budaya yang besifat universal.Disetiap daerah memiliki cara-cara tersendiri dalam melaksanaan tradisi untuk memperingati masa-masa yang penting dalam suatu kehidupan dengan melakukan suatu upacara adat.Ritual upacara adat dilaksanakan berdasarkan tradisi yang ada secara turun temurun yang diwariskan oleh nenek moyang mereka.Bagi masyarakat Suku Sasak upacara daur hidup dalam ritual upacara adat kelahiran, perkawinan sampai ritual kematian merupakan jenjang keberadaan manusia di dunia ini. Diantara kelahiran, perkawinan dan kematian itu akan tercipta rangkaian-rangkaian peristiwa yang merupakan lingkaran kehidupan manusia.

$$
\text { Van Gennep dalam Daeng (2012: 145) }
$$
mengatakan bahwa dalam tahap peralihan, manusia sejak dia lahir kemudian masa anak-anak, dewasa, menikah, hingga meninggal dunia, manusia mengalami proses peralihan dalam lingkungan sosial budayanya yang dapat 
menimbulkan krisis mental yang berpengaruh terhadap jiwa individu. Untuk menghadapi masa peralihan ini maka, diperlukan serangkaian upacara peralihan.Teori van Genep dalam Daeng kaitannya dengan riual masyarakat Suku Sasak bahwa dalam kepercayaan dan kehidupan masyarakat melewati siklus peralihan.Ritual siklus peralihan yang ada pada masyarakat Suku Sasak setiap tahap yang dilalui selalu diiringi dengan upacara karena mencerminkan kewajiban seseorang terhadap dunia roh.Kepercayaan tersebut mengakibatkan masyarakat Suku Sasak mengadakann ritual ritual yang terkait dengan kehidupan yang mencakup seluruh tahapan kehidupan manusia semenjak dilahirkan hingga menikah yaitu upacara beretes, molang malik, dan nyunatang.

Peristiwa kelahiran bagi masyarakat Desa Pengadangan merupakan peristiwa yang sakral yang disambut dengan berbagai upacara yang berbau kulturdan religius.Ritual upacara adat kelahiran ini sebagai tradisi turun temurun yang dilaksanakan oleh masyarakat yang bertujuan mencari keselamatan dan ketentraman dalam hidup. Melalui ritual upacara adat kelahiran ini masyarakat menyakini bahwa Tuhan dan nenek moyang mereka yang sudah tiada akan melindungi mereka dalam hidupnya. Pelaksanaan ritual ini merupakan salah satu tradisi yang terkait dengan kepercayaan masyarakat akan adanya suatu malapetaka yang nantinya akan terjadi terhadap anak-anak mereka.Apabila seorang istri hendak melahirkan, maka mereka segera mencari belianatau dukun yang mengetahui seluk beluk pristiwa kelahiran. Dalam melahirkan anaknya, calon ibu mengalami kesulitan maka belian menafsirkan hal tersebut sebagai akibat tingkah laku sang ibu sebelum hamil. Hal tersebut biasanya ditafsirkan akibat berlaku kasar terhadap ibu atau suaminya. Untuk itu diadakan upacara, seperti menginjak ubun-ubun, meminum air bekas cuci tangan suami dan ibunya ini dilakukan agar mempercepat kelahiran sang bayi.Setelah bayi tersebut lahir masyarakat menganggap bahwa rambut yang dibawa lahir oleh bayi disebut bulu panas.Oleh karena itu rambut tersebut dihilangkan dengan mengadakan selamatan, doa atau upacara sederhana yang disebut ngrusiang.Orang pertama yang memotong rambut bayi tersebut adalah seorang kiyai.Kiyai pada masyarakat Desa Pengadangan merupakan orang yang sangat dihargai dan dipercaya dalam memimpin prosesi ritual.Masyarakat Desa Pengadangan mempercayai bahwa anak yang baru lahir dan belum di molangmalliqkan sangat rentan dengan bahaya. Oleh karena itu sang bayi tidak diizinkan untuk keluar rumah sebelum dilakukan molangmaliq tersebut.

Selain dari adat molang malik, upacara nyunatang atau khitanan sangat unik dan berbeda dengan daerah lainnya yaitu sebelum upacara dilaksanakan masyarakat beramai-ramai pergi membasuh beras ke tempat mata air yang mengalir dengan diiringan musik gamelan.Pada malam harinya juga tidak lepas dari keramaian dari wayang kulit yang diadakan untuk menghibur orang-orang yang sedang memasak. Setelah itu dilakukan ritual kereman kepada anak yang akan dikhitan ditempat-tempat yang dianggap keramat oleh masyarakat Desa Pengadangan. Masyarakat mempercayai adanya roh-roh jahat atau hal-hal yang ghaib yang akan mengganggu anak cucu mereka apabila belum dilaksanakannya ritual-ritual adat dalam upacara adat kelahiran, karena ritual dalam upacara adat kelahiran ini dipercayai sebagai upacara yang bisa melindungi anak cucu mereka dari segala gangguan yang ada di alam sekitar mereka. Karena, Tuhanlah yang akan menjadi keselamatan sejati bagi manusia, bahwa manusia tidak mampu sendiri untuk memperoleh keselamatan itu oleh karena itu manusia hanya menyerahkan diri kepada Tuhan. Simbol yang nampak pada pelaksanaan upacara adat ini adanya benda-benda yang digunakan dan tempat yang dipakai dalam setiap ritual adat. Benda-benda tersebut seperti pinang, sirih, bokor, mondo, telor, pinang, gunting, kembang, air, benang. Benda lain yang digunakan seperti tikar dan jajanan tradisonal masyarakat setempat serta tempattempat yang dikeramatkan.

Bustanuddin (2006: 96) menyebutkan bahwa upacara yang tidak dipahami kongkritnnya dinamakan rites yang berarti tindakan atau upacara keagamaan.Upacara ritual merupakan kegiatan yang dilakukan secara rutin oleh sekelompok masyarakat yang diatur dengan hukum adat masyarakat yang berlaku.Upacara ritual memiliki aturan dan tatacara yang telah ditentukan oleh masyarakat atau kelompok dari pencipta ritual tersebut, sehingga masing-masing ritual 
memiliki perbedaan baik dalam pelaksanaan maupun perlengkapan.Dalam pelaksanan ritual adat kelahiran wajib dilaksanakan karena sebagai keselamatan bagi anakanak mereka.Masyarakat Suku Sasak menganggap bahwa menjalankan ritual adat kelahiran ini merupakan sebagai suatu kewajiban mereka untuk memohon keselamatan dan tanggung jawab masyarakat terhadap adat yang sudah diwariskan oleh nenek moyang mereka.

Ritual upacara adat kelahiran ini sebagai upacara untuk mencari keselamatan dan bukti tentang keyakinan yang dimiliki oleh masyarakat tentang adanya kekuatan yang Maha Dahsyat diluar kekuatan manusia.Ritual upacara adat juga sebagai bentuk rasa syukur kepada Tuhan, leluhur yang telah memberikan keselamatan dan kelancaran dalam pelaksanaan ritual adat kelahiran.Menurut Koentjaraningrat (2004: 202) upacara religi atau ritual adalah wujud sebagai sistem keyakinan dan gagasan tentang Tuhan, dewa-dewa, roh-roh halus, neraka, surga, dan sebagainya tetapi memiliki wujud yang berupa upacara-upacara, baik bersifat musiman maupun yang kadangkala.Masyarakat Suku Sasak yang berada di Desa Pengadagan melaksanakan ritual upacara adat kelahiran ketikan seorang ibu yang sedang hamil 7 bulan sampai melahirkan dan anak yang dikandungnya telak beranjak besar. Ritual ini dilakukan sebagai upacara selametan yang nantinya akan membawa keselamatan terhadap bayi yang dikandungnya. Pelaksanaan ritual tersebut dilakukan sebagai media untuk memohon keselamatan, mengucap syukur kepada Tuhan Yang Maha Esa dan mengungkapkan rasa hormat kepada leluhur mereka.Masyarakat Pengadangan melaksanakan ritual adat kelahiran tersebut sebagai upacara adat yang sakral.

Didalam melaksanakan upacara adat tidak terlepas dengan sesaji-sesaji yang harus disiapkan. Sesajisesaji tersebut berupa makanan, jajanan tradisonal dan pembakaran kemenyan yang dilakukan pada saat upacara akan dilakukan. Kelengkapan sesaji sudah menjadi kesepakatan bersama yang tidak boleh ditinggalkan karena sesaji ini merupakan sarana pokok dalam ritual. Setiap kegiatan ritual yang dilakukan oleh masyarakat Desa Pengadangan mengandung makna simbolik yang terdapat didalamnya seperti sesaji, doa, waktu dan tempat pelaksanaannya. Semua ini dilakukan sebagai media untuk mendekatkan diri kepada Tuhan Yang Maha Esa dan kepada leluhur mereka yang sudah meninggal dunia.Setiap tahapan pelaksanaan ritual upacara adat kelahiran banyak mengandung makna simbol yang berhubungan dengan aspek religi, bahkan makna dari simbol tersebut dijadikan sebagai fungsi simbol dalam setiap upacara adat. Upacara adat kelahiran mengandung berbagai macam norma dan atauran yang harus dipenuhi. Norma tersebut tumbuh dan berkembang dalam kehidupan masyarakat secara turun temurun yang berfungsi untuk melestarikan ketertiban hidup dalam setiap ritual.

Makna simbol terdapat pada perlengkapan yang digunakan pada saat pelaksanaan ritual.Perlengkapan yang digunakan seperti ancak, rereke, dan bahan makanan serta jajanan tradisonal Suku Sasak.Ancakmelambangkan tulang rangka dalam tubuh manusia.Pemakaian ancak sebagai alas dalam pembuatan rereke merupakan sebuah penggambaran bahwa manusia tidak dapat hidup layak di tengah-tengah masyarakat jika tidak memiliki pegangan hidup sendiri.Selain itu, penggunaan ancak juga dilakukan sebagai tanda bahwa setiap masyarak mengikuti hukum adat yang berlaku pada masyarakat Desa Pengadangan. Masyarakat Desa Pengadangan meyakini bahwa dalam kehidupan manusia pasti akan mengalami berbagai macam warna kehidupan yakni pahit, senang, susah yang dilambangkan dari hidangan dalam acara adat. Hidangan tersebut berupa makanan dan berbagai macam jajanan tradisional yang berfungsi melambangkan kemajemukan watak dari setiap individu.Pelaksanaan upacara adat kelahiran juga sebagai upacara adat yang melambangkan bahwa dalam setiap pelaksanaannya masyarakat mantaati segala aturan yang harus dilakukan dalam pelaksanan ritual.

Ritual upacara adat kelahiran sebagai media untuk memohon keselamatam dan rasa syukur atas segala kemudahan yang diberikan oleh Tuhan Yang Maha Esa.Pelaksanaan upacara adat kelahiran ini sebagai upacara keagamaan yang melambangkan bahwa disetiap ritual yang dilakukan dengan doa-doa.Selain itu upacara adat kelahiran ini sebagai sarana hiburan bagi masyarakat.Seni hiburan ini nampak pada pelaksanaan upacara adat beretes dan nyunatang.Didalam pelaksanaan upacara beretes seni hiburan tampak pada saat 
pelaksanaan pemandian di sungai. Seseorang yang akandiretes dibawa kesuangai dengan diiringi dengan suara-suara musik gamelan yang menjadi hiburan bagi masyarakat yang ikut dalam prosesi pemandian. Seni hiburan juga nampak pada pelaksanaan upacara adat nyunatang. Sebelum pelaksanaannya orang yang memiliki hajatan akan menyewakan berbagai macam seni hiburan tradisional yang ada di Desa Pengadangan. Tujuannya untuk menyenanngkan hati para warga masyarakat yang senantiasa dengan senang hati membantu dalam setiap proses pelaksanaan adat nyunatang. Selain itu, diadakannya perajaan terhadap anak yang akan dikhitan yang berfungsi agar anak yang dikhitan nantinya tidak takut dalam mennghadapi khitanannya. Perajaan juga sebagai hiburan kepada warga masyarakat yang tidak bisa menyaksikannya langsung kerumah orang syang edang melaksnakan adat tersebut.Selain itu, brfungsi sebagai sarana komunikasi dalam masyarakat.Di lihat dari pelaksanaannya upacara adat kelahiran ini sejak persiapan, perlengkapan, pelaksanaan hingga ahir upacara melibatkan berbagai pihak terutama masyarakat Desa Pengadangan.Upacara adat kelahiran ini sebagai sarana untuk mempererat hubungan antar sesama manusia.Ini terlihat pada pelaksananaan suatu upacara adat, masyarakat tidak bisa melakukannya dengan sendiri, oleh karena itu dibutuhkan bantuan dan pertisipasi keluarga dan masyarakat disekitarnya.

Pelaksanaan upacara adat kelahiran ini tidak terlepas dari kepercayaannya kepada seseorang individu yang akan membantu dalam kelancaran upacara adat. Masyarakat Desa Pengadangan sesalu mempercayakan pelaksanaan upacara adat ini kepada orang yang benarbenar bisa memberikan keselamatan kepada anaknya yaitu kepercayaan masyarakat terhadap orang yang dituakan atau seorang kiyai. Seorang kiyai ini nantinya akan membantu dalam pelaksanaan upacara adat sebagai pemimpin upacara adat dan sebagai orang yang akan mendoakan anak mereka. Seperti dalam pantun yang diungkapkan bahwa Salak gebuk pade rau, nganak bembek Dasan Lian, salak tuduh jari tau, salak sembek sik belian. Makna dari pantun ini apabila seseorang melaksanakan upacara adat harus benar-benar memilih orang atau kyai yang benar-benar memiliki agama yang kuat sehingga tidak akan melakukan kesalahan dalam setiap upacara adat.

Kepercayaan masyarakat tersebut diatas dilandasi karena adanya keyakinan yang dimiliki oleh masyarakat setempat.Sebagai manifestasi dari agama dan kepercayaan yang dianut oleh masyarakat, Upacara adat kelahiran juga tentunya memiliki fungsi sosial bagi masyarakat sebagai pengokoh kekuatan moral. Hal itu senada dengan pandangan Broom dan Selznick dalam Narwoko (2006: 253) mengungkapkan bahwa setiapmasyarakat bisa tetap eksis dan survive karena sikap kooperatif dari anggotaanggotanya. Sifat kooperatif antarwarga masyarakat itu sendiri diperoleh melalui jalur sosialisasi, dan agama adalah sumber utama proses sosialisasi yang dimaksud. Karena itu, agama berperan memberikan sokongan psikologis. Agama selain membantu orang lain dari kebingungan dunia dan menawarkan jawaban tentang berbagai permasalahan, juga memberikan kekuatan moral. Upacara adat kelahiran mencerminkan bahwa semua perencanaan, tindakan dan perbuatan telah diatur oleh tata nilai luhur.Tata nilai yang dipancarkan melalui upacara adat merupakan manifestasi tata kehidupan masyarakat Suku Sasak yang serba hati-hati dalam setiap pelaksanaannya.Nilai-nilai upacara adat kelahiran pada masyarakat Desa Pengadangan diwariskan secara turun temurun dari satu generasi kegenerasi selanjutnya. Proses tersebut berjalan secara alami dalam keseharian kehidupan masyarakatnya. Masyarakat Desa Pengadangan menerima nilai-nilai dari upacara adat kelahiran ini mulai dari lingkungan keluarga, dimana sejak kecil mereka diajarkan untuk selalu mentataati segala ketentuan adat istiadat yang telah berlaku dari zaman nenek moyang mereka.Nilai-nilai upacara adat kelahiran ini seperti solidaritas, menghormati hakikat hidup, tanggung jawab, ketaatan, ketertiban, dan kebaikan.Selain itu memiliki nilai keindahan, keterpaduan, kekompakan kerjasama, kerja keras, dan keuletan.Selain itu adanya nilai agama dilihat dari bentuk doa-doa yang dilakukan pada saat pelaksanaan ritual untuk kelancaran jalannya ritual adat. Kemudian nilai sosial bisa dilihat pada waktu persiapan dan pelaksanaan ritual yang melibatkan berbagai pihak terutama masyarakat Desa Pengadangan, nilai budaya bisa dilihat dari pelaksanaannya dimana masyarakat saling 
bekerja sama, dan nilai pendidikan dilihat dari cara masyarakat menjaga hubungan yang baik dengan sesama masyarakat yang mengajarkan sikap terpuji, jujur, seti, berani, dan berbuat baik kepada sesamanya.

Nilai yang menonjol dalam pelaksanaan upacara adat kelahiran ini adalah nilai kerjasama.Pelaksanaan upacara adat kelahiran ini sangat nampak bahwa antara masyarakat yang satu dengan masyarakat yang lainnya saling membantu.Kerjasama menumbuhkan sikap saling menghargai perbedaan diantara masyarakat. Masyarakat Suku Sasak Desa Pengadangan dalam mempertahankan adat kelahiran ini ditopang oleh masyarakat pendukungya, seperti dalam pelasanaan upacara adat masyarakat selalu bergotong rotong dalam mempersiapkan dan melaksanakan proses upacara. Selain itu, didukung oleh sistem kepercayaan masyarakat yang beranggapan bahwa jika tidak melakukan suatu upacara adat akan menimbulkan suatu yang buruk terhadap anak mereka.Secara sosiologis bahwa pelaksanaan kegiatan upacara adat kelahiranmemberikan makna sebagai alat pemersatu bagi masyarakat.Hal itu dapat dilihat dari simbol yang diberikan berupa penggunaan perlengkapan yang digunakan.Ritual tersebut menggambarkan adanya nilai sosial budaya yang dijunjung tinggi oleh masyarakat. Melalui pelaksanaan ritual tersebut masyarakat secara tidak langsung mendapatkan pesan akan pentingnya menjaga nilai-nilai di antara mereka sebagai sebuah sistem nilai sosial budaya.

Person dalam Ritzer dan Goodman (2007: 121) menyatakan bahwa Sistem cenderung menuju ke arah pemeliharaan keseimbangan diri yang meliputi pemeliharaan batas dan pemeliharaan hubungan antara bagian-bagian dengan keseluruhan sistem, mengendalikan lingkungan yang berbeda-beda dan mengendalikan kecenderungan untuk mengubah sistem dari dalam.sebagai sebuah sistem sosial budaya, masyarakat melalui pelaksanaan ritual seperti itu menjadi sebuah langkah konkrit yang dilakukan untuk menjaga nilai integrasi sosial di antara mereka. Hal ini merupakan sebuah hal yang sangat penting karena dalam integrasi, hal yang perlu diperhatikan adalah proses internalisasi dan sosialisasi.Berpijak dari hal tersebut, maka dapat dikatakan bahwa ritual upacara adat kelahiran merupakan sebuah bentuk sosialisasi untuk menanamkan nilai integrasi sosial kepada masyarakat agar mereka sadar dan memahami bahwa mereka adalah sebuah sistem yang perlu menjunjung tinggi nilai solidaritas sosial di antara anggota masyarakat yang ada di Desa Pengadangan.

Selain dari nilai-nilai yang ada pada upacara adat tersebut, peran pemerintah sangat penting dalam mempertahankan upacara adat kelahiran ini dilihat dari prosesi pelaksanaan upacara adat.Pemerintah tidak meyarankan setiap masyarakat untuk melakukan upacara adat secara besar-besaran, pemerintah hanya melihat ketaatan masyarakat dalam melakukan suatu upacara adat.Pelasanaan upacara adat ini walaupun tidak dilakukan secara besar-besaran asalkan prosesinya itu sesuai dengan ketentuan yang sudah berlaku sejak zaman nenek moyang masyarakat Suku Sasak.Dari sinilah kita bisa tetap mempertahankan warisan budaya sehingga dapat berkembang sampai sekarang ini.Pewarisan budaya Suku Sasak ini bertumpu pada peran orang tua pada keluarga dimana anak-anak mereka diajarkan untuk selalu mentaati adat istiadat yang berlaku sehingga tertanam dalam diri anak-anak mereka sebagai anggota masyarakat. Proses ini kemudian berjalan terus menerus melalui proses sosialisasi antara masyarakat yang satu dengan yang lainnya dan langsung diterapkan dalam kehidupan sehari-hari sejak awal pada masa kanak-kanak hingga meninggal dunia. Setiap individu atau masyarakat menerima pengetahuan, keterampilan, sikap, motivasi, dan disposisi yang membuat mereka beradaptasi dan berpartisipasi serta mempertahankan diri dalam masyarakat secara kolektif (Zen, 1993: 278).

Dalam mempertahankan upacara adat kelahiran ini didukung pula oleh nilai-nilai dari upacara adat kelahiran tersebut dan sistem kepercayaan masyarakat yang beranggapan bahwa jika mereka tidak melakukan suatu upacara adat mereka takut akan terjadi sesuatu yang buruk menimpa anak cucu mereka. Menurut Koentjaraningrat (1990: 376) bahwa semua aktivitas manusia yang bersangkutan dengan religi berdasarkan atas suatu getaran jiwa, biasa disebut emosi keagamaan (religious emotion). Emosi keagamaan inilah yang akan mendorong orang melakukan tindakan-tindakan yang bersifat religi, bahkan suatu benda, suatu tindakan dan 
gagasan, mendapat suatu nilai keramat, dan dianggap keramat.

Masyarakat Desa Pengadangan percaya bahwa dengan mejalankan ketentuan-ketentuan adat yang ada berarti mereka dapat menghormati nenek moyang mereka dan sebagai tanda syukur mereka terhadap Tuhan Yang Maha Esa. Ketentuan adat merupakan hal yang harus diikuti, Karena apabila ketentuan-ketentuan adat itu tidak dilakukan dikawatirkan sesuatu yang buruk akan menimpa anak-anak mereka. Pemerintah Dinas Pariwisata memandang bahwa dalam mempertahankan upacara adat kelahiran yang diyakini oleh masyarakat Suku Sasak Desa Pengadangan harus diakui, dihormati, dilindungi, dan diperhatikan untuk dilestarikan dan dikembangkan sebagai aset budaya pemerintah Desa Pengadangan khususnya di Lombok Nusa Tenggara Barat.

Adat istiadat masyarakat Suku Sasak Desa Pengadangan terdapat beberapa ketentuan yang masih berlaku hingga sekarang ini seperti: (a) Dalam melakukan upacara adat beretes tidak diperbolehkan bertepatan dengan orang meninggal, karena akan menimbulkan sesuatu yang tidak baik bagi kandungannya. Menurut kepercayaan masyarakat Desa Pengadangan anak yang dikandungnya akan meninggal, tetapi hidup dan mati itu hanya Allah yang tau. Oleh sebab itu setiap ada yang meninggal bertepatan dengan upacara besembetakan digantikan dengan seekor ayam yang dihayutkan kesungai ditempat besembet dilakukan. (b) Bagi kaum laki-laki dilarang memotong rambut pada waktu istrinya sedang mengandung, itu akan mengakibatkan perut sang istri gatal-gatal dan akan timbul bintik-bintik merah. (c) Anak yang baru lahir tidak diperbolehkan keluar rumah sebelum dilakukan upacara adat molangmaliq.

\section{TEMUAN ATAU DISKUSI}

Berdasarkan Penelitian yang telah dilakukan maka terdapat beberapa temuan dalam upacara adat kelahiran yang dilakukan diantaranya: (1) Masyarakat Suku Sasak melaksanakan upacara adat kelahiran karena merupakan warisan dari leleuhur dan adanya ketakutan terhadap gangguan yang akan menimpa anak cucu mereka; (2) Kurangnya pengetahuan masyarakat terhadap proses pelaksanaan ritual adat sehingga mengakibatkan perubahan dalam fungsi dan nilainya; (3) Kurangnya peran pemerintah dalam mensosialisasikan tradisi-tradisi budaya yang ada pada masyarakat Suku Sasak sehingga mengakibatkan tradisi budaya lokal banyak tergerus oleh arus globalisasi sekarang ini.

\section{E. SIMPULAN DAN SARAN}

1. Simpulan

a) Pelaksanaan upacara adat kelahiran dilaksanakan diberbagai tempat di Desa Pengadangan yaitu di masjid, di Musholla, dan dirumah-rumah penduduk yang hendak melaksanakan hajatan.Upacara adat kelahiran bertepatan dengan pelaksanaan Maulid Nabi Muhammad SAW dan hari raya idul fitri.Setiap pelaksanaan adat selalu berkaitan dengan sesaji ataupun yang lainnya sehingga banyak yang bertentangan tetapi masyarakat Desa Pengadangan masih tetap mempertahankan adat yang sudah berlaku sejak zaman nenek moyang mereka. Pelaksanaan upacara adat memiliki perlengkapan yang sama dengan perlengkapan upacara lainnya. Perlengkapan yang digunakan yaitu benang, beras, dan embet. Ketiga perlengkapan tersebut memiliki makna yang berbedabeda teteapi memiliki satu tujuan yaitu supaya ibu dan anak yang diupacarakan diberi keselamatan dan dijauhkan dari hal-hal yang ghaib.

b) Adat kelahiran ini memiliki fungsi spiritual antara manusia dengan Tuhannya.Upacara adat kelahiran ini tetap dilaksnakan oleh masyarakat Desa Pengadangan karena menghormati para leluhurnya. Selain itu, sebagai ungkapan rasa sukur atas segala perlindungan yang diberikan oleh Tuhan. Rasa syukur ini diungkapkan dengan berbagai cara seperti bersodakoh dan melakukan selamatan. Selain itu upacara adat sebagai kebutuhan fungsi sosial bagi masyarakat Desa Pengadangan. Kebutuhan sosial tersebut merupakan kebutuhan berkomunikasi dengan sesama anggota masyarakat, kebutuhan untuk saling tolong menolong, dan kebutuhan bersama dalam hal melestarikan tradisi leluhur. Selain itu, memiliki sikap batin bahwa segala sesuatu merupakan milik bersama, dipelihara bersama dan dimanfaatkan bersama sehingga melahirkan system kegotong royongan dan tolong menolong tanpa mengharapkan imbalan.Selain itu upacara adat 
kelahiran tidak terlepas dari bentu pendidikan terhadap nilai-nilai yang menggambarkan dalam bentuk benda seperti rereke. Rereke ini tersebut merupakan makanan yang dikemas dlam perlengkapan upacara.

\section{Saran}

a) Bagi masyarakat pengadangan, hendaknya warisan budaya dari pelaksanaan upacara adat kelahiran ini harus ditanamkan kepada generasi selanjutnya, agar generasi selanjutnya bisa mengetahui serentetan dari prosesi ritual dalam upacara adat kelahiran.

b) Bagi pihah-pihak yang ikut dalam pelaksanaan upacara adat kelahiran, supaya tidak menghilangkan fungsi dari pelaksanaan adat kelahiran dan tetap menjunjung tinggi nilai-nilai dari upacara adat kelahiran agar tidak diwarnai dan dipengaruhi oleh budaya asing agar fungsidan nilai dari upacara adat kelahiran yang ada pada masyarakat Suku Sasak tidak tergerus oleh budaaya asing.

c) Bagi masyarakat Suku Sasak yang ada di Lombok diharapkan agar dalam pelaksanaan upacara adat kelahiran tidak meninggalkan syariat islam yang merupakan agama dari masyarakat Suku Sasak meski ritual yang dilakukan harus sesuai dengan ketentuan dari para leluhur mereka.

\section{DAFTAR RUJUKAN}

Daeng, J. Hans. 2012. Manusia, Kebudayaan dan Lingkungan. Yogyakarta: Pustaka Pelajar.

Koentjaraningrat. 1990. Sejarah teori Antropologi II. Jakarta: Universitas Indonesia(UI-Press).

Koenjaraningrat.2002. Kebudayaan Mentalitas dan pembangunan. Jakarta: Gramedia Pustaka.

Budiwanti, Erni. 2000. Islam Sasak, Wetu Telu Versus Waktu Lima. Yogyakarta: LKis.

Bustanuddin, Agus. 2006. Agama Dalam Kehidupan Manusia: PengantarAntropologi Agama. Jakarta: Rajawali Perss.

Koenjaraningrat. 2004. Manusia dan Kebudayaan di Indonesia. Jakarta: Djambatan.

Matitaputty, Jenny. 2010. Nilai-Nilai Kearifan Adat Dan Tradisi Di Balik Ritual Daur Hidup (Life Cycles) Pada Masyarakat Suku Nuaulu Di Pulau Seram
Sebagai Sumber Pembelajaran IPS (Studi Etnografi di Desa TamilouKecamatan Amahai Kabupaten Maluku Tengah).

Narwoko, Dwi J. dan Bagong Suyanto.2006. Sosiologi Teks Pengantar Dan Terapan Edisi Kedua. Jakarta : Kencana.

Ritzer, George dan Doglas J. Goodman.2007. Teori Sosiologi Modern Edisi Keenam. Jakarta: Kencana.

Zen, Mohammad. 1993. Pendidikan Tradisi Berbagai Budaya Sebagai WahanaPengembangan Sistem Pendidikan Nasional. Bandung: UniversitasPendidikan Indonesia. 